\title{
Partition of Proteins in Aqueous Two-phase Systems Based on Cashew-nut Tree Gum and Poly(ethylene glycol)
}

\author{
Leonie Asfora Sarubbo ${ }^{1 *}$, Luciana Alves de Oliveira ${ }^{2}$, Ana Lúcia Figueiredo Porto ${ }^{3,4}$, Galba \\ Maria de Campos-Takaki ${ }^{1}$ and Elias Basile Tambourgi ${ }^{2}$ \\ ${ }^{1}$ Departamento de Química; NPCIAMB; Universidade Católica de Pernambuco; Rua Nunes Machado, 42, \\ Bloco J, Térreo; Boa Vista; 50050-590; Recife - PE - Brazil. ${ }^{2}$ DESQ-FEQ; UNICAMP; Campinas - SP - Brazil. \\ ${ }^{3}$ Laboratório de Imunopatologia Keizo Asami; UFPE; Recife - PE - Brazil. ${ }^{4}$ Departamento de Morfologia e \\ Fisiologia Animal; UFRPE; Recife - PE - Brazil
}

\begin{abstract}
The partitioning of two proteins, bovine serum albumin (BSA) and trypsin was studied in an aqueous poly(ethylene glycol)(PEG)- Cashew-nut tree gum system. The phase diagram was provided for Cashew-nut tree gum and PEG molecular weight of 1500 at two different temperatures. The influence of several parameters including concentrations of polymers, $\mathrm{pH}$, salt addition and temperature on the partitioning of these proteins were investigated. The results of this research demonstrated the importance of the protein characteristics for partitioning in aqueous biphasic system.
\end{abstract}

Key words: Aqueous two-phase systems, bovine serum albumin, Cashew-nut tree gum, protein partition

\section{INTRODUCTION}

Aqueous two-phase systems (ATPS) composed of water and two soluble polymers have found widespread use in biochemical research for separation and purification of macromolecules, cells and cell particles (Albertsson et al., 1981; Walter et al., 1985). ATPS can easily be scaled up without an appreciable change in the nature or efficiency of the process. In addition, since there is no solid phase, through mixing of the two phases is possible and hence interface transport is rapid. Very little time is required to bring most two-phase systems into equilibrium. Another benefit is that the phases are compatible with almost all known proteins. They are an attractive alternative procedure for the separation and purification of proteins on a large scale. The question of selectivity in protein partitioning still needs to be better understood. An increased knowledge of protein behaviour in aqueous-two phase systems will also lead to the ability to predict the partitioning of specific materials (Silva and Franco, 2000).

The most widely used system for protein extraction has been the one consisting of dextran and poly(ethylene glycol) (PEG) (Johansson 1984, 1985; Tjerneld et al., 1986). However, the high cost of fractionated dextran has limited the use of this system for large scale isolations. Therefore, developing aqueous two-phase systems based on new and cheaper polymers have been a challenging research goal (Pietruszka et al., 2000). We have shown recently an economic watersoluble acidic heteropolysaccharide gum from Anacardium occidentale L. (Cashew-nut tree) found in Brazil (Sarubbo et al., 2000; Oliveira

\footnotetext{
* Author for correspondence
} 
et al., 2002) that has the potential to act as an alternative to fractionated dextran in aqueous twophase systems.

To define a successful purification system, it is desiderable to understand the main physicochemical parameters that affect protein partitioning. The present study investigated the use of PEG-Cashew-nut tree gum ATPS for the partitioning of proteins.

\section{MATERIALS AND METHODS}

\section{Materials}

Bovine serum albumin (BSA), trypsin and Poly (ethylene glycol) (PEG) 1500 were obtained from Sigma Chemical Co. (St. Louis, Mo, USA). Crude gum was collected as natural exudate from cultivated Anacardium occidentale trees of various localities in Pernambuco State, Brazil. Commontype plants about 20 years old, yellow cashew producers were utilised. All other chemicals were analytical grade.

\section{Purification of gum}

Clear nodules free of bark were selected to purification using ethanol (Rodrigues et al., 1993).

\section{Phase Diagrams}

Phase diagrams were determined at room temperature according to Albertsson's procedure (Albertsson, 1986). The binodal of the phase diagram, the demarcation between PEG-Cashewnut tree gum compositions showing monophasic and biphasic behaviour was obtained by direct observation of two phase formation for a large number of solutions containing varying concentrations of PEG and Cashew-nut tree gum. Systems that displayed a distinct phase/phase interface were considered biphasic and their top and bottom phases polymer composition were analysed. PEG concentration was determined according to Skoog (1979). Polysaccharide concentration was determined by measuring reducing sugars (Miller, 1959) concentration after a hydrolysis step with sulphuric acid.

\section{Two-phase systems}

The systems were prepared from stock solutions of polymers in water, $30 \%(\mathrm{w} / \mathrm{w})$ cashew-nut tree gum and $70 \%(\mathrm{w} / \mathrm{w})$ PEG. The polymers solutions were weighed and mixed with phosphate buffer ( $\mathrm{pH}$ 6.0, 7.0 and 8.0), according to the desired $\mathrm{pH}$.
The buffer concentration was $15 \mathrm{mM}$. Total weight of system was $4 \mathrm{~g}$. The systems were well vortex mixed for $5 \mathrm{~min}$ and then centrifuged at 236 $g$ during 5 minutes to obtain two clear phases. The partition experiments were performed at $25^{\circ} \mathrm{C} \pm 2^{\circ}$ and $40^{\circ} \mathrm{C} \pm 2^{\circ}$ by mixing systems with a $400 \mu \mathrm{l}$ of a $2 \mathrm{mgml}^{-1}$ protein solution. The study of protein partitioning was carried out at $\mathrm{pH}$ 6.0, 7.0 and 8.0 for two different tie-line lengths. Systems containing salts (pH 7.0) were prepared by dissolving powdered salt directly into the systems for salt concentrations of $0.1 \mathrm{M}$ or $1 \mathrm{M}$.

\section{Protein Partitioning}

Protein concentration in the top phase was determined according to Bradford (1976) and partition coefficient $(\mathrm{K})$ was defined as the ratio between protein in the upper (PEG) and lower (Cashew-nut tree gum) phases. Samples of the top phase were diluted in water, when necessary, and analysed for protein concentration. The protein concentration of the bottom phase, due to its viscosity, was calculated from mass balance, according to Venâncio et al. (1993) and Almeida et al. (1998). Protein concentration was determined for a set of three independent systems.

\section{RESULTS AND DISCUSSION}

Phase diagram for the system PEG-Cashew-nut tree gum system at $25^{\circ} \mathrm{C} \pm 2^{\circ}$ and $40^{\circ} \mathrm{C} \pm 2^{\circ}$ is displayed in Fig. 1. It could be seen that there was no significant displacement between the curves for the two temperatures studied. This result has already been reported for other systems (Albertsson, 1986). The carbohydrate polymer was enriched in the denser bottom phase while PEG was found in the upper phase. The total system compositions for the tie-lines and temperatures studied are given in Table 1 and 2.

The distribution of BSA and trypsin in PEG1500Cashew-nut tree gum systems was studied by the addition of protein solutions to stock solutions of both phases. The experimental results obtained showed that both proteins concentrated in the Cashew-nut tree gum-rich bottom phase (Fig. 2). The increase of the tie-line length in most cases led to a decrease of $\mathrm{K}$. The effect of polymer concentration could be attributed to the excluded volume effects that increased with increasing PEG concentration (Albertsson, 1986). Similar results 
were obtained for other polymer-polymer systems (Almeida et al., 1998; Christian et al., 1998; Kishida et al., 1998).

The effect of $\mathrm{pH}$ on the partition coefficients varied between proteins and with the type of system. The partition coefficients were obtained for BSA and trypsin at pH 6.0, 7.0 and 8.0. In this $\mathrm{pH}$ range, both proteins have net molecular charge. BSA was negatively charged (pI 5.1) while trypsin was positively charged (pI 9.2). BSA and trypsin partitioning showed little variation by changing the system $\mathrm{pH}$, but a little increase of $\mathrm{K}$ could be detected as the $\mathrm{pH}$ was increased from 6.0 to 8.0 for both proteins (Fig. 2).

Although these proteins exhibited different properties, the similar trend observed could be influenced by other factors, such as conformation and specific interactions with phase-forming polymers. Proteins partition coefficients in PEG 1500-Cashew-nut tree gum systems at $\mathrm{pH} 8.0$ were not determined for the second tie-line length (13.8\% PEG-22.5\% gum) since the system turned uniphasic (homogeneous) after the addition of protein solution.

The small but significant unequal distribution of the small ions in the phases creates a partition potential between the phases. This potential in turn affects the distribution of the charged particles, such as proteins. Due to the large number of charges on these macromolecules, their behaviour is affected by the partition potential. The mechanisms that cause the uneven distribution of biomolecules are poorly understood and the ATPS widespread use has been limited because of the complexity of predicting the partition of materials.

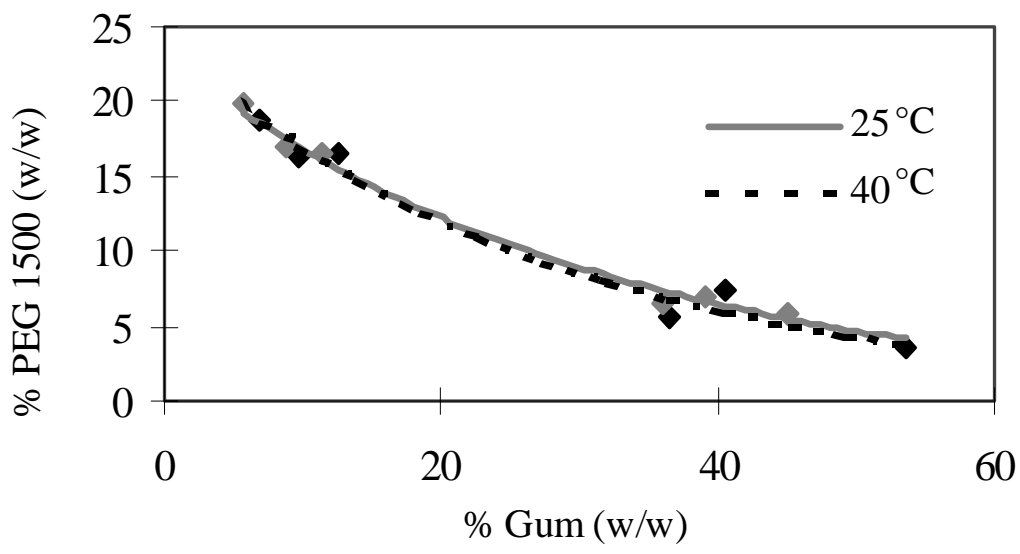

Figure 1- Phase diagram for the system PEG1500-Cashew-nut tree gum at $25^{\circ} \mathrm{C} \pm 2^{\circ}$ and $40^{\circ} \mathrm{C} \pm 2^{\circ}$

Table 1- Tie-lines composition (w/w) of PEG1500-Cashew-nut tree gum system at $25^{\circ} \mathrm{C}$

\begin{tabular}{lcc}
\multicolumn{1}{c}{ PEG 1500 } & \multicolumn{2}{c}{ Tie-line } \\
\cline { 2 - 3 } & $\mathbf{1}$ & $\mathbf{2}$ \\
\hline System composition & & 22.5 \\
Gum & 21.0 & 13.8 \\
PEG & 13.0 & 63.7 \\
$\mathrm{H}_{2} \mathrm{O}$ & 66.0 & 5.75 \\
\hline Top phase composition & & 19.89 \\
Gum & 8.73 & 74.36 \\
PEG & 16.91 & 45.15 \\
$\mathrm{H}_{2} \mathrm{O}$ & 74.36 & 4.73 \\
Bottom phase composition & & 49.12 \\
\hline Gum & 39.20 & \\
PEG & 7.0 & \\
$\mathrm{H}_{2} \mathrm{O}$ & 53.80 & \\
\hline
\end{tabular}


Table 2- Tie-lines composition (w/w) of PEG1500-Cashew-nut tree gum system at $40^{\circ} \mathrm{C}$

\begin{tabular}{lcc}
\hline \multicolumn{1}{c}{ PEG 1500 } & \multicolumn{2}{c}{ Tie-line } \\
\cline { 2 - 3 } & $\mathbf{1}$ & $\mathbf{2}$ \\
\hline System composition & & 22.5 \\
Gum & 21.0 & 13.8 \\
PEG & 13.0 & 63.7 \\
$\mathrm{H}_{2} \mathrm{O}$ & 66.0 & 6.76 \\
\hline Top phase composition & & 18.86 \\
\hline Gum & 9.74 & 74.38 \\
PEG & 16.29 & \\
$\mathrm{H}_{2} \mathrm{O}$ & 73.97 & 50.48 \\
\hline Bottom phase composition & & 3.67 \\
Gum & 40.58 & 45.85 \\
PEG & 7.26 & \\
$\mathrm{H}_{2} \mathrm{O}$ & 52.16 & \\
\hline
\end{tabular}
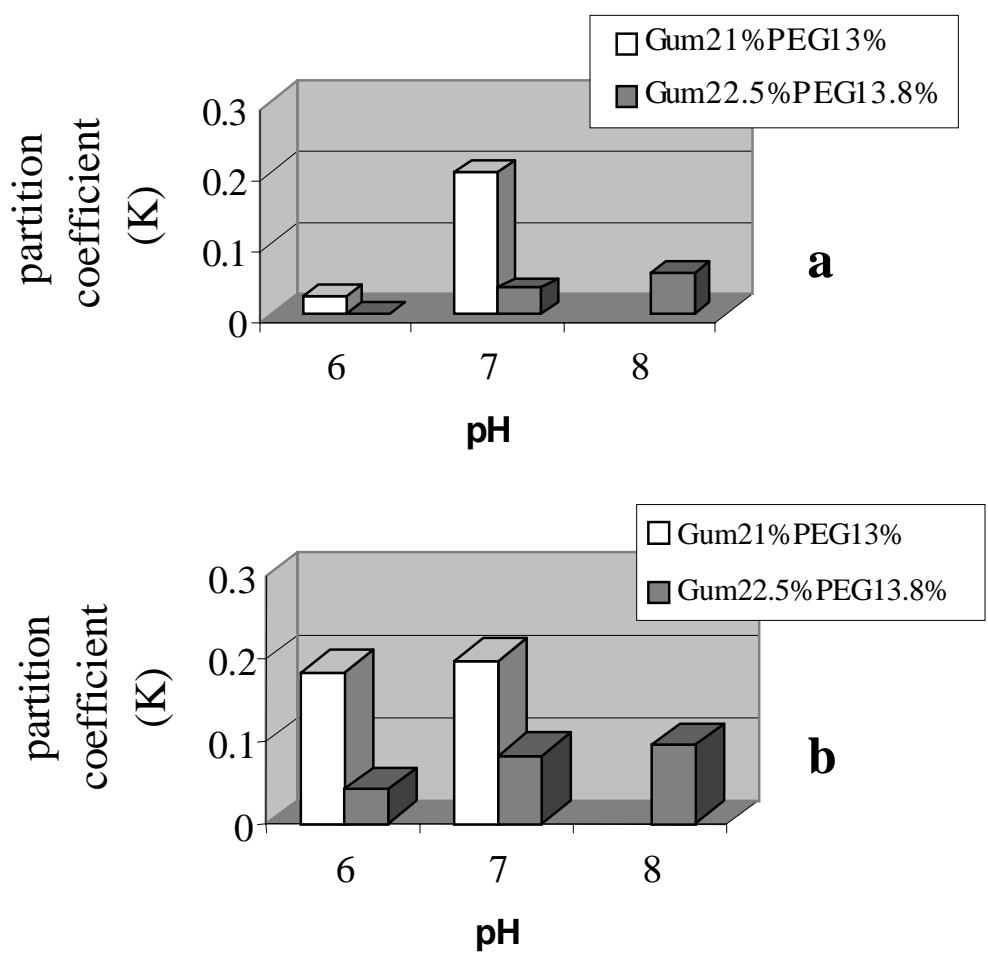

Figure 2- Effect of tie-line length and $\mathrm{pH}$ on $\mathrm{BSA}$ (a) and trypsin (b) partition coefficients in PEG1500-Cashew-nut tree gum system at $25^{\circ} \mathrm{C} \pm 2^{\circ}$

The influence of $\mathrm{NaCl}$ addition on the partition of BSA and trypsin at pH 7.0 is shown in Fig. 3. It was observed that the BSA partition coefficient decreased for $0.1 \mathrm{M} \mathrm{NaCl}$ addition and increased for $1.0 \mathrm{M} \mathrm{NaCl}$ addition for both tie-lines length. Similar results were obtained by Venâncio et al. (1993) for negatively charged proteins partitioned in polymer-polymer systems. BSA partitioning in PEG-Arabinigalactan systems (Christian et al.,
1998) and in PEG-Aquaphase PPT (Sturesson et al., 1990) decreased after the addition of $0.1 \mathrm{M}$ $\mathrm{NaCl}$ for systems at $\mathrm{pH}$ 7.0.

The trypsin partition coefficient decreased proportionally to the $\mathrm{NaCl}$ concentration only for the first tie-line. Results obtained by Almeida et al. (1998) for cutinase partitioning in PEG-Reppal PES systems with $0.1 \mathrm{M} \times 1.0 \mathrm{M} \mathrm{NaCl}$ at positive 
pH's showed an irregular partition trend with $\mathrm{NaCl}$ concentration.

By the analysis of the system composition, considering low salt concentrations, a small predominance of the chloride ion in the PEG-rich phase can occur, which becomes electrically more negative compared to the lower phase. Thus, the negatively charged substances are preferentially partitioned into the lower phase. The results obtained for BSA partitioning after the addition of $0.1 \mathrm{M} \mathrm{NaCl}$ at $\mathrm{pH} 7.0$, where the protein had a negative charge, agreed with the explanation described above. However, for trypsin, which was positively charged at $\mathrm{pH} 7.0$, such behaviour could not be observed. Probably, other factors might have influenced the partitioning in a different way as there existed a lot of parameters involved (e.g. hydrophobic interactions, concentration and phase-forming polymer properties and affinity of the macromolecule for the phase-forming polymer).
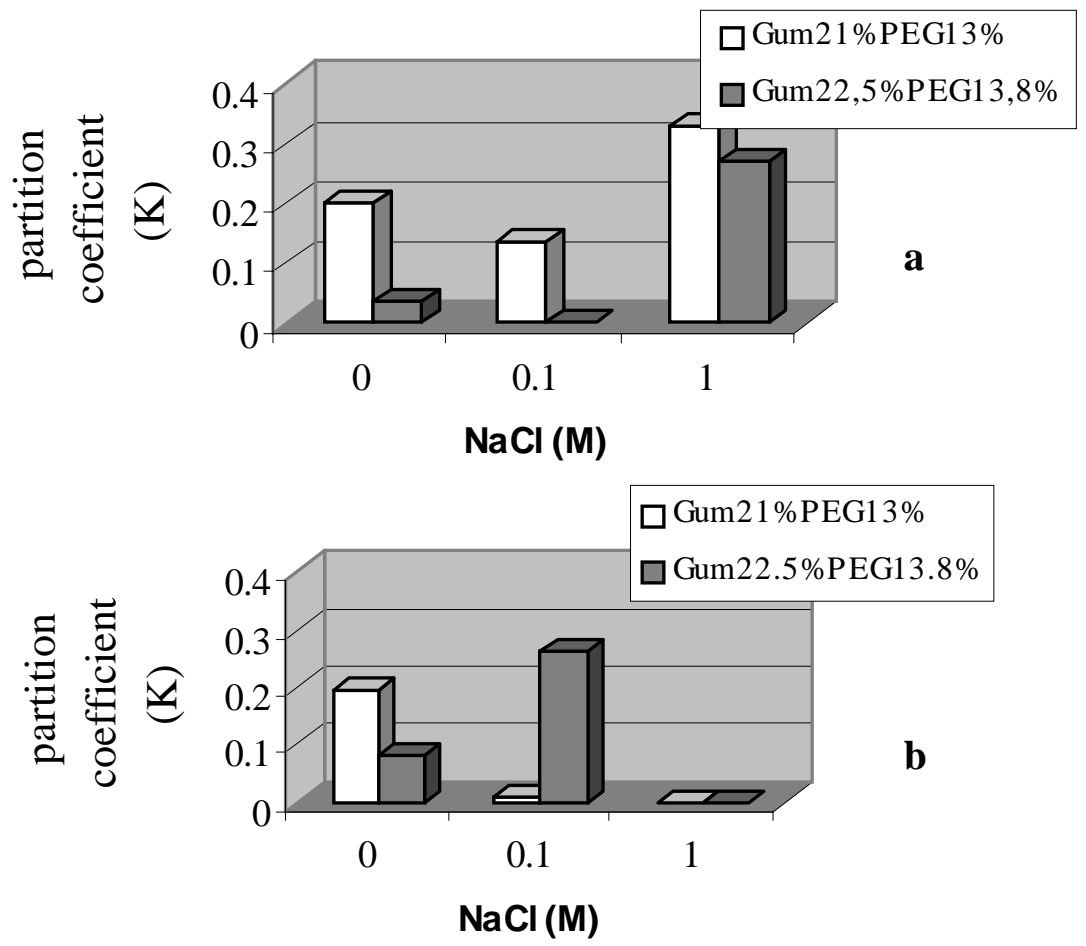

Figure 3- Effect of $\mathrm{NaCl}$ addition on BSA (a) and trypsin (b) partition coefficients in PEG1500-Cashew-nut tree gum system at $25^{\circ} \mathrm{C} \pm 2^{\circ}, \mathrm{pH} 7.0$

The effect of temperature is quite complex because the phase composition, the electrostatic interactions and the hydrophobic interactions are all coupled to the temperature. In addition, the proteins can undergo denaturation, conformational changes, and self association or dissociation when the temperature is raised. Some reports have described an increase in the partition coefficient with the temperature (Diamond and Hsu, 1992; Forciniti et al., 1991), others have found that the partition coefficient showed no temperature dependence (Johansson et al., 1973; Tjerneld et al., 1985). The effect of temperature on the partition coefficient of BSA and trypsin was studied at $25^{\circ} \mathrm{C} \pm 2^{\circ}$ and $40^{\circ} \mathrm{C} \pm 2^{\circ}$ (Fig. 4). The results showed a little increase of $\mathrm{K}$ of trypsin with temperature, while BSA partitioning showed an opposite behaviour. 

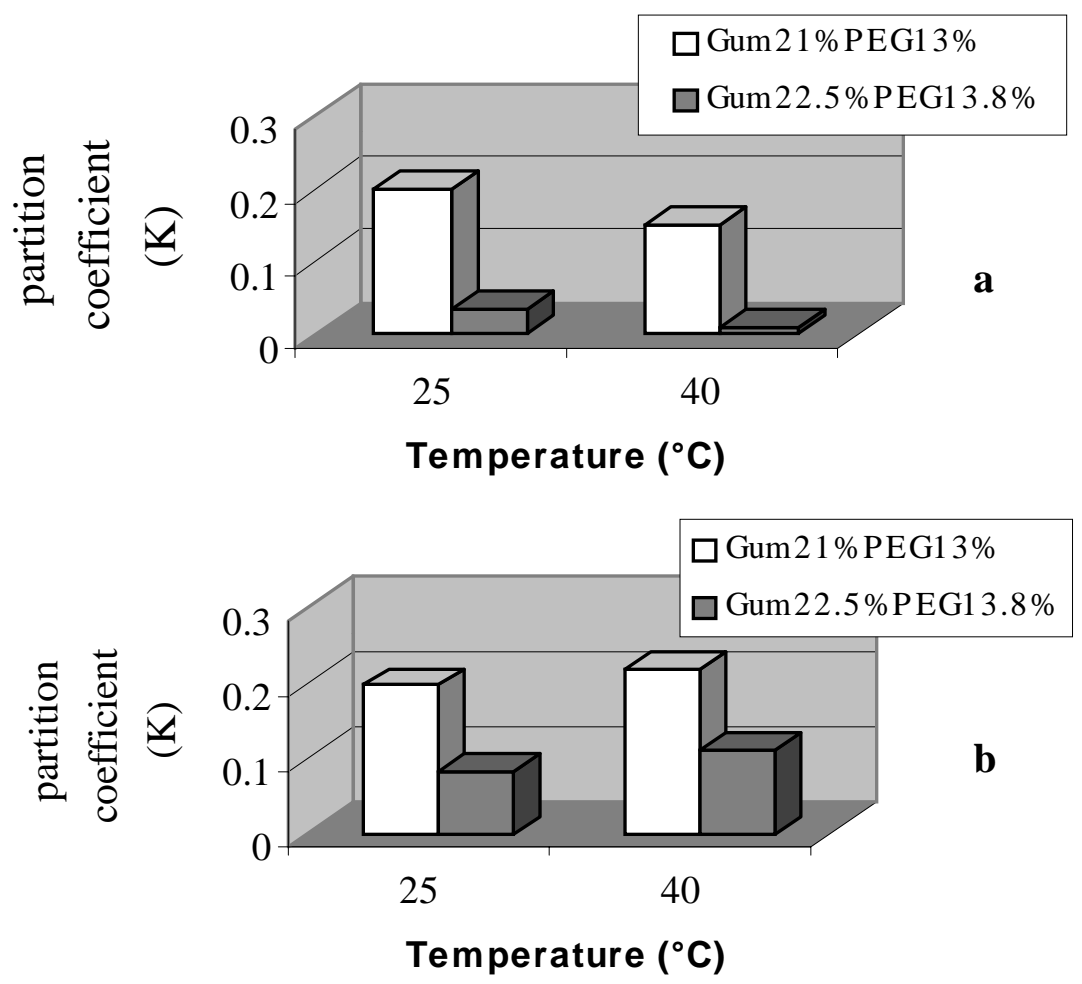

Figure 4- Effect of temperature on BSA (a) and trypsin (b) partition coefficients in PEG1500-Cashew-nut tree gum system at $\mathrm{pH} 7.0$

As there was no significant change in phases composition in the PEG-Cashew-nut tree gum system when temperature was changed, the influence of this parameter on the partition coefficient seemed to be highly dependent on other factors, such as the kind of protein which is partitioned. These results showed that there could be many factors that influenced the partitioning behaviour of proteins in aqueous two phase systems. The complexity of the partitioning because of the involvement of several interacting properties between the solute and the phase forming components was related.

\section{CONCLUSIONS}

The partitioning of two proteins, BSA and trypsin, even with different characteristics showed similar traits when the influence of some parameters was investigated. The results obtained showed that it was possible to change the degree of partitioning by selecting the right conditions like $\mathrm{pH}$, temperature and salt addition.

\section{ACKNOWLEDGEMENTS}

We would like to thank FAPESP and PRONEX/CNPq for financial support.

\section{RESUMO}

A partição de duas proteínas, albumina de soro bovino (BSA) e tripsina foi estudada no sistema bifásico aquoso Polietileno glicol(PEG) - Goma do cajueiro. O diagrama de fases foi estabelecido para a Goma do Cajueiro e para PEG de peso molecular $1500 \mathrm{em}$ duas diferentes temperaturas. A influência de vários parâmetros na partição destas proteínas, incluindo concentração dos polímeros, $\mathrm{pH}$, adição de sal e temperatura foi investigada. Os resultados desta pesquisa demonstraram a importância das características da proteína na partição em sistemas bifásicos aquosos. 


\section{REFERENCES}

Albertsson, P. A. (1986), Partition of Cell Particles and Macromolecules. $3^{\text {rd }}$ ed. New York : Wiley.

Albertsson, P. A.; Andersson, B.; Larsson, C. and Akerlund, H. E. (1981), Methods Biochem. Anal., 28, 115-150.

Almeida, M. C.; Venâncio, A.; Teixeira, J. A. and Aires-Barros, M. R. (1998), Cutinase purification on poly(ethylene glycol)-hydroxypropyl starch aqueous two-phase systems. J. Chrom. B., 711, 151-159.

Bradford, M. M. (1976), A rapid and sensitive method for the quantification of microgram quantities of protein utilizing the principle of protein-dye binding. Anal. Biochem., 72, 248-254.

Christian, T. J.; Manley-Harris, M. and Richards, G. N. (1998), A preliminary study of the use of larch arabinogalactan in aqueous two-phase systems. Carbohydr. Polym., 35, 7-12.

Diamond, A. D. and Hsu, J. T. (1992), Aqueous two phase systems for biomolecule separation. $A d v$. Biochem. Eng., 47, 89-135.

Forciniti, D.; Hall, C. K. and Kula, M. R. (1991), Temperature dependence of the partition coefficient of proteins in aqueous two-phase systems. Bioseparation, 2, 115-128.

Johansson, G.; Anderson, M. and Akerlund, H. E. (1984), Counter current distribution of yeast enzymes with polymer-bound triazine dye affinity ligands. $J$. Chrom., 289, 483-49.

Johansson, G.; Hartman, A. and Albertsson, P. A. (1973), Partition of proteins in two-phase systems containing charged poly(ethylene glycol). Eur. $J$. Biochem., 33, 379-386.

Johansson, G. and Joelsson, M. (1985), Preparation of Cibacron blue F3GA (polyethylene glycol) in large scale for use in affinity partitioning. Biotechnol. Bioeng., 27, 621-625.

Kishida, A.; Nakano, S.; Kikunaga, Y. and Akashi, M. (1998), Synthesis and funcionalities of poly (N-vinylalkylamide). VII. A novel aqueous twophase systems based on poly(N-vinylacetamide) and Dextran. J. Appl. Pol. Science., 67, 255-258.

Miller, G. L. (1959), Use of dinitrosalicylic acid reagent for determination of reducing sugar. Anal. Chem., 31, 426-428.

Oliveira, L. A.; Sarubbo, L. A.; Porto, A. L. F.; Lima-Filho, J. L.; Campos-Takaki, G. M. and Tambourgi, E. B. (2002), Physical and rheological characterisation of PEG-Cashew-nut tree gum aqueous two-phase systems. J. Chrom. B., 766, 27-36.

Pietruszka, N.; Galaen, I. Y.; Kumar, A.; Brzozowski, Z. K. and Matiasson, B. (2000), New polymers forming aqueous two-phase polymer systems. Biotechol. Prog., 16, 408-415.
Rodrigues, J. F.; Paula, R. C. M. and Costa, S. M. (1993), Métodos de isolamento de gomas naturais: comparação através da goma do cajueiro (Anacardium occidentale L.). Polímeros: Ciência e Tecnologia, 1, 31-36.

Sarubbo, L. A.; Oliveira, L. A.; Porto, A. L. F.; Duarte, H. S.; Carneiro-Leão, A. M. A.; Lima-Filho, J. L.; CamposTakaki, G. M. and Tambourgi, E. B. (2000), New aqueous two-phase system based on cashew-nut tree gum and polyethylene glycol. J. Chrom. B., 743, 79-84.

Silva, M. E. and Franco, T. T. (2000), Liquid-liquid extraction of biomolecules in downstream processing - a review paper. Braz. J. Chem. Eng., 17, 1-30.

Skoog, B. (1979), Determination of polyethylene glycols 4000 and 6000 in plasma protein preparations. J. Blood Transf. Immunopathol., 37, 345-349.

Sturesson, S.; Tjerneld, F. and Johansson, G. (1990), Partition of macromolecules and cell particles in aqueous two-phase systems based on hydroxypropyl starch and poly(ethylene glycol). Appl. Biochem Biotechnol., 3, 281-295.

Tjerneld, F.; Berner, S.; Cajarville, A. E. and Johansson, G. (1986), New aqueous two-phase system based on hydroxypropyl starch useful in enzyme purification. Enzyme Microbiol. Technol., 8, 417-423.

Tjerneld, F., Persson, I. and Albertsson, P. A. (1985), Enzymatic hydrolysis of cellulose in aqueous two-phase systems. I. Partition of cellulases from Trichoderma reesei. Biotechnol. Bioeng, 27, 1036-1043.

Venâncio, A. A. D.; Almeida, C.; Domingues, L. and Teixeira, J. A. (1993), Protein partition on a derivative guar gum based aqueous two-phase system. Bioseparation, 5, 253-258.

Walter, H.; Brooks, D. E. and Fisher, D. (1985), Partitioning in Aqueous Two-Phase Systems: Theory, Methods, Uses, and Applications to Biotechnology. Orlando : Academic Press.
Received: April 28, 2003; Revised: September 30, 2003 . Accepted: February 06, 2004. 